\title{
Education Empowerment of Madrasah at Fisherman Society in Suku Laut Kuala Tungkal Jambi
}

Received: $13^{\text {th }}$ July 2020; Revised: $10^{\text {th }}$ Desember 2020; Accepted: $29^{\text {th }}$ Desember 2020

Permalink/DOI: https://doi.org/10.15548/jt.v27i3.635

\section{Syahran Jailani *)}

Universitas Islam Negeri Sulthan Thaha

Saifuddin Jambi Indonesia

E-mail: m.syahran@uinjambi.ac.id

\section{Makmur Haji Harun}

Sulthan Idris Education University, Malaysia

E-mail: makmur@fbk.upsi.edu.my

\section{*) Corresponding Author}

\begin{abstract}
This study aims to reveal the education Empowerment of Madrasah at Fisherman society in Suku Laut Kuala Tungkal Jambi. Islamic schools are generally born from the initiation of society as a form of concern for the condition of the people, especially children in understanding the special religion of Islam as a matter of doubt. This research was conducted by using qualitative approach where the data collection methods and data validity. The result showed that the schools have contributed greatly to Indonesian education not only in providing a religious understanding, but also in participating to educate the children of the nation through the educational process that has lasted tens or even hundreds of years. In its journey, the empowerment of Islamic schools experienced various dynamics, commitment of Islamic school leadership, public awareness and supporting efforts became the issue that made Islamic schools hard to develop as expected.
\end{abstract}

Keywords: Education empowerment of Madrasah; fishermen society; Islamic education.

How to Cite: Jailani, M., \& Harun, M. (2020). Education Empowerment of Madrasah at Fisherman Society in Suku Laut Kuala Tungkal Jambi. Al-Ta lim Journal, 27(3), 258-270. doi:https://doi.org/10.15548/jt.v27i3.635

\section{INTRODUCTION}

The implementation of education in an advanced state and nation, superior, quality and dignity, because the nation puts education as a priority for human resource development mentions, education or more comprehensive human resource development is most strategic element for development of the nation state (Leo \& Wickenberg, 2013). Burga (2019) explicitly states that "progressive retreat of culture and civilazation of a nation is determined how much access to education for society as a whole". Davis \& Sumara (2008) states that "education is an area of work through which one can hope to improve the quality of life". Raising and gaining degrees in human life, humans do not necessarily grow and develop by it self and passed without process. The long process that an individual (human) passes through is called an "educational process" (Dimitriadis \& Kamberelis, 2006; Kellner, 2003; Ladson-Billings \& Tate, 2006).

Islamic School with same missions and duty are like other educational institutions, not only transfer of knowledge to learners (children) (Hasan, 2009; Hussain, 2004; Tan, 2015). Moreover, the Islamic school as educational institution gives contribution education and social to society and children, as well as fostering of next generation who have the power of religious belief values (Halik, 2016; 
Merry, 2018). It can be seen in their daily behaviors. The mission and noble task of Islamic School as moral institution formation of learners is believed to be able to become a da'wah mission both personal, family and society (Mundiri, 2017; Muthmainnah et al., 2020). He mentioned that Islamic school has a specific character, it is not only to carry out educational and religious teaching tasks, but also to provide life guidance". Therefore, Islamic School belongs to society and integrates with values that have been lived and developed within the culture as belonging to society. The National Education System Act number 20/2003 Chapter III Article 4, states that; (1) education is conducted in a democratic and just and nondiscriminatory way by upholding human rights, religious values, cultural values, and national pluralism, (2) education is organized as a systemic system with open system and various meaning, (3) education is held as a process of cultivating and empowering learners which lasted throughout life, (4) education is organized by giving exemplary, build a wanted, and develop the creativity of learners in the learning process, (5) education is held by developing the culture of reading, writing, and counting for all citizens, and (6) education is organized by empowering all components of society through participation in the implementation and quality control of education services.

Admittedly, sometimes educational institutions such as Islamic School has not been optimal to empower children's potential and provide something meaningful for their life through the learning process, moreover the empowerment of society who become bigger shareholders presence Islamic School in the middle society, Islamic School often considers and low-class institutions (Daun \& Arjmand, 2005; Douglass \& Shaikh, 2004; Hilgendorf, 2003; Salleh, 2013). Whereas Islamic School is one of the pillars of educational institution component that is expected to be able to mobilize and empower of society to make the awareness process of the importance of education, and make education for all children become the vehicle to reach the ideals without distinguishing the background of life. The case of the life of fisherman village $S u k u$ Laut Kuala Tungkal in education is a fact that there are some Islamic School around them whose presence has not been the concern of parents and children of what they should get about education. Islamic School has not been an important part of exploring religious knowledge and another knowledge. Although they realize that the Islamic School is also a place to learn religion.

\section{METHOD}

This research was conducted by using qualitative approach. to find meaningfulness, with an approach using Spradley's steps (Spradley, 2016). Sampling in this study refers to the Spradley's criteria. They are: (1) the subject has been long and intensive "fused" with an activity or "activity field" targeted research attention; (2) subjects who are still fully engaged / active in the research activities; (3) a subject having sufficient time or opportunity to request information; (4) subject who giving information does not tend to be "processed" or "packed" first; and (5) a subject previously classified as "foreign" to the researcher so that they may feel more challenged to "learn" as much as possible from a subject is like a new teacher to themselves.

Data collection methods is used in this research as Denzin (2009) suggested, namely observation, interview, documentation and use non-human sources, as well as recording the results of data collection. Also supported by direct interaction with subject researchers such as, listening, seeing, talking, asking, asking for explanations, expressing and capturing the implicit gestures of subject involved. For a data validity test, referring Lincoln, 
(2007) suggests of using: (1) credibility standards; (2) transfers standard; (3) dependability standard; and (4) confirm ability standard. The data analysis technique is used in this research based on the opinion of Spradley (2016), that is; (1) domain analysis, (2) taxonomy analysis, 3) componential analysis and (4) cultural themes.

\section{RESULT AND DISCUSSION}

Geographically Fisherman Village Suku Laut Kuala Tungkal is in the position of $0^{\circ} 45-1^{\circ} 27$ South Latitude (LS) and $102^{\circ} 38-104^{\circ} 33$ East Longitude. With the area of Tungkal II $\pm 1.080 \mathrm{Ha}$, from the total area of Tungkal Ilir District covering $\pm 320,100 \mathrm{Ha}$. Located $125 \mathrm{KM}$ from the Capital of Province or $1440 \mathrm{KM}$ from the Capital of Republic Indonesia Jakarta. Judging from the topography, the fisherman village located at Tungkal II Village, located in lowland marshy and mud-covered soil mangrove trees, palm trees and flame trees. With the category of tidal areas that usually occur twice during 24 hours. Large tides occur in DecemberApril. The Location is on the shoreline with a height of $0-2,5 \mathrm{M}$ from sea level. Fisherman Village Suku Laut Kuala Tungkal belongs to the subtropical region which is generally humid / wet climates, where rainfall is almost uniform throughout the year of 2,000-3000 $\mathrm{M}^{3}$ with an average temperature of $23{ }^{\circ} \mathrm{C}$ and a maximum of $32^{\circ} \mathrm{C}$.

All the population of Tungkal II Village is 8,792 people. From the total population of Tungkal Ilir sub-district totaled 111,694 inhabitants. From 8,792 residents of Tungkal Ilir, 4,362 men and 4,430 women. While the number of residents especially from Suku Laut amounted to 400 people or 177 families. From the 177 families, there are 151 families living below the poverty line or the underprivileged society. (see attached Kelurahan data).

Table1: Population Data of Kelurahan Tungkal II

\begin{tabular}{ccc}
\hline Male & Female & Total \\
\hline 4.362 people & 4.430 people & 8.792 people \\
\hline Source: Monogram of Kelurahan Tungkal II, 2015 &
\end{tabular}

According to the population data of Kelurahan Tungkal II, residents of the Fisherman village are in four
Neighborhood Association (RT) is RT. 001, RT. 009, RT. 17, and RT. 003.

Table 2: Population Data of Suku Laut by sex.

\begin{tabular}{cccc}
\hline No. & Genre & People & Percentage \\
\hline 1. & Male & 193 & $48,3 \%$ \\
2. & Female & 207 & $51,7 \%$ \\
3. & Total & 400 & $100 \%$ \\
\hline
\end{tabular}

Source: Information Secretary of Lurah Tungkal II, 2015

Generally, fisherman of $S u k u$ Laut at Kuala Tungkal, living in groups inhabiting along the shore of spreading river which directly opposite Berhala strait and South China Sea. According to one of Suku Laut Mr. AB, put forward as follows:
"Before we settled and lived on land, we used to live and stay in large and small boats according to family size. The boat we use was called a "dekang" boat consisting of three parts. The front of the boat was the children life, the center of the bed consisting of 
children's and parents' bedrooms, the backside was usually a cooking place and animal pets such as birds, cats and other pets. New 1920s, our tribe began to settle and live on land. With consideration remain not far from the sea. Actually, the term "Bajau" according to our people Suku Laut is not a proper name given to us, because our people own Suku Laut does not mention the term of Bajau, Bajau itself is given to other communities outside Suku Laut. Our people Suku Laut itself is called Suku Laut with the title "Suku Dono or Duano". Its means people are mobile. (Interview Sunday, September 13 ${ }^{\text {th }}$, 2017. at 04.00 PM).

Based on history trail search. The first-time people who inhabit / settle fisherman village is derived from the people of Suku Laut. Their origins are based on some reliable sources, it concludes that Suku Laut society at Kuala Tungkal originates from Johor (Malaysia). When interpreting the term "Bajoe" itself which stands for "Baa" means "Nation" and "Joe" meaning "Joehor". So Bajoe means "Joehor Nation", then the term contains a sense that signifies the element of sociological closeness between understandings of Bajoe with a particular society. It means there is a historical truth that cannot be refuted. Another version, based on the results of research report STAIS An-Nadwah Kuala Tungkal in 1992. As quoted in the book "Studies in Moro History, Law and Religion" composed Juan. G. F Zaide published in 1991. Describes the historical origins of the people of Suku Laut (Bajau), as follows:

"In $1380 \mathrm{AD}$, Islam began to enter Philippines had brought by a preacher from Arab country named "Mak Dum". Then in 1390 the mission of da'wah was followed by Rajo Bagindo from Minangkabau West Sumatra. Subsequently, in 1450 AD a preacher from Palembang named Abu Bakar, he succeeded in entering the Sulu archipelago (South of Manila) to develop and register the syiar of Islam for decades. In $1475 \mathrm{AD}$, an Arab merchant named Sharif Kebungsuan, he married the Tumina Princess on the southern Philippine island of Mindanao, and in the end, he became king in kesulthanan Miindanau and its surroundings. From the islands of Sulu and Mindanao, Islam spread its territory to the Luzon archipelago to the north of the Philippines bordering the island of Sulawesi. And finally, in know $1571 \mathrm{AD}$, for the first time the Islamic kingdom stood in the Philippines under the rule of a king Sulthan Sulaiman. In 1569 AD, the Spanish (European) came to Philippine who originally just stopped by. Because of the fertile nature and potential wealth and strategic position, over time the Spanish people have a desire to master. What's more when the Philippines, especially Manila city, the majority of Islam is still very simple and not so advanced in civilization. Inflation took place and the war was inevitable, the Spanish colonized and seized all the rights of the people of Philippines and its surroundings, the war of devil took quite a long time for almost 300 years. Year 1876 AD in continue by America who had colonized the territory of the Philippines and ended in 1914 AD. As a result, colonizing hundreds of years old, the Spanish in addition to master the potential of nature also perform mission of religion spreading. The people of Philippines were forced to convert from Islam which originally had a religious faith to convert to Catholicism. As a result, many Filipinos look for shelter by sailing to nearby islands to southern Philippines such as Moro, Mindanau, Sulu and Zamboanga. Some have fled for days until settled to the Sulawesi Island, 
Borneo, even to Sumatra Island, especially on the east coast of Sumatra, such as Riau Islands, South Sumatra and even Kuala Tungkal (Jambi)."

Among the socio-cultural life of the fisherman society Suku Laut at Kuala Tungkal still strongly maintained is habit before to the sea, which is by doing ritual activities in the form of prayers interspersed with incense as a condition to avoid the calamity or avoid the danger at sea and when returning from sea welcome to at home. Avoiding abstinence such as prohibition of carrying baskets (made of rattan), forbidden to say dirty, to suck at sea, or to perform dishonest acts. When that is done, usually the catch does not produce the expected results. When viewed from the characteristics of body shape / physical, visible characteristic of the Fisherman Society Suku Laut at Kuala Tungkal, for example the color of blackish skin, the shape of foot either male or female in the form of $\mathrm{O}$, and walking slightly bent, more prominent hips, molar teeth protruding fore, wide sole of foot and between the end of foot with the heel almost flat. Other customs, it seems difficult to change from the fisherman village and especially Suku Laut is the habit of speaking loudly. For those of us who just meet them, with seeing them to speak as if they are fighting.

Generally, the fisherman village society, especially Suku Laut society at Kuala Tungkal, from the recognition of Islam status, is seen from the identity card (KTP) listed. From the result of researcher observation in the field shows that their Islam status no together with religious practice as desired by the provisions of the Shari'a. Religious practices (Islam) are not carried out, for example when the time of zhuhur, ashar, or magrib prayers are not implemented. They are busy with their respective activities. Even if there are religious activities of Islamic holidays such as the activities of Isra 'mi'raj, mawlid of Prophet Muhammad SAW, or the activities of Islamic New Year by presenting $d a^{\prime} i$ (lecturer) from out of town / city only few come. In this fisherman village location, there are three mosques / langgar, most of them to fill time of five-time prayers, precisely outside of Suku Laut society.

With limited religious knowledge, it is not supported by sufficient religious understanding, making most of them parents away from religious practices that should be done. It is reasonable that if their children are also far away from religious practice, this is evident from the author's observation when visiting one of the Hidayatus Shobiyah Qur'an Exhibition Park (TPA), from fifty children 0-6 years old, children $6-12$ years to study holy book only 3-5 children from Suku Laut society the rest outside children of Suku Laut society. In family situation, affect religious life and social relationships of children greatly. Religious values that children should accept early on do not occur, and the condition are more severe with the neighborhood around settlement is not conducive to support children's education process. For example, there is a billiard ball game place that should be based on rules should not be around settlement. A domino card game is performed by adults, it's located adjacent to society's homes, indirectly seen by children.

The presence of Islamic School at the fisherman village Suku Laut at Kuala Tungkal is very helpful for parents in participating to educate the nation's children, although around at the fisherman village Suku Laut at Kuala Tungkal has been established State Elementary School for example: State Elementary School 14 / V, State 
Elementary School 24 / V and State Elementary School 190 / V Kuala Tungkal, but it did not reduce the intention and intention of religious leaders and community leaders to establish Islamic School, especially Ibtidaiyah Islamic School. This cannot be separated from strong desire of religious leaders and public figures that dried so that the children around fisherman village have sufficient religious knowledge for the future of children at the next time. This recognitionis obtained by researcher through interviews with society leaders such as H. S. A (70 years) stated that:

"The presence of Islamic School in the fisherman village was originally to anticipate the many children here who have not been able to read the Qur'an and write Arabic Malay, and usually in the afternoon these children play more which I value less useful. So, on the initiative of society leaders and religious leaders of which there was once a religious figure among Suku Laut is called uztaj AA, agreed to establish Islamic School for children to know and understand with Islam and hope in the future these children can run the teachings of religion correctly" (interview on Saturday, September $12^{\text {th }}$ 2017 at 05.00 PM).

In its journey, Religious Islamic School of Tarbiyah at Kuala Tungkal experienced a fairly good development, especially early in the 1970s, and suffered a setback several years later resulting from them, namely:

Islamic School leadership system that still adheres to ewuh pakewuh in among the teachers (uztaj/uztajah) who retained the head of Islamic School by seniority (although the visionary and prospective teachers) did not change from the quality of the graduates nor the development of Islamic School, although the quantity of students/santri exceeded the capacity of study space,
2) Development of Islamic School has not received any real support from related parties, for example: the lack of help from study room buildings from the Ministry of Religious Affairs of the District and Province, the district government, and the absence of assistance from private-owned enterprises investing around fisherman village, and (3) the teacher's competence who abandoned to be the general educator of graduates at Aliyah Islamic School with the intention of sincere charity, although if there is not temporary employee unequivalent to work as educator.

Tarbiyah Islamic school fisherman village at Kuala Tungkal one of many Islamic School which held learning process by using learning approach that general is used at Islamic School in Indonesia, example: using arabic melayu holy book, remaind ayat-ayat in short surah and it doesnot use national curriculum which is applicable at school run by National Education Ministry. It means that curriculum that used by using curriculum semi boarding school, although not all of school usedboarding school model. The result of interview from a teachers(ustaj) revealed as follow:

"The curriculum is used in Islamic School Tarbiyah Islamiyah is based on the curriculum of which is boarding school generally used by boarding schools at Kuala Tungkal, although not all the subject matter uses the curriculum of boarding school. This can be seen from the holy books are used by the teacher (uztaj / uztajah), for example: fiqh holy book in arabic Malay, tawheed holy book in arabic Malay language, and juridical jurisprudence holy book, Tasyriful wadhi 'sharaf science and others" (interview on Saturday, September $19^{\text {th }} 2017$ at 04.30 PM). 
The leadership of the Tarbiyah Islamic school fisherman village of Kuala Tungkal refers to the tradition / model of boarding school leadership generally puts teachers (uztaj) who master deep religious knowledge and more senior in terms of age and teaching experience. Although this tradition / model has been going on for a long time from one leadership to another, the aspect of Islamic school empowerment has not brought significant change. For example: the empowerment of teachers (uztaj / uztajah) that have not been maximized well, even among teachers (uztaj / uzadajah) have skills other than teaching, such as: writing calligraphy skill, promise nazhom, or reading skill of recite Al-Qur'an. Supposedly, the expertise teachers (uztaj / uztajah) become attraction of Tarbiyah Islamic school to attract children to enter Islamic school.

The result of research found that several factors who affect Islamic School had not yet became a favorite place to learn such as: (1) Parent's perception of Islamic School. Generally, parents assumed school in elementary school more given ease, especially in terms of cost, because at elementary school, the children entered and free of cost, even Islamic School could help from the government, (2) socialization and promotion of Islamic School. Although Islamic School existed before elementary school was established, the children interest to study at Islamic School was not a pride for fishermen parents of Kuala Tungkal, besides the parent's perception who still looked at studying in Islamic School as a place that had not guaranteed the future. Socialization approach and promotion of Islamic School was as a good place to gain knowledge, not only science of worldliness but also sciences relating to religion.
Based on the results of research, the empowerment of education at Islamic schools in Fisherman village Suku Laut Kuala Tungkal, aspects of the background of both sociological and historical, educational science aspects, approach of religion aspect. Comprehensive empowerment of Islamic schools will eventually lead to educational institutions and institutional figures which have strong and proud character, not only for the leadership of respective Islamic schools Principals, but also to bring the atmosphere of enlightenment in the midst of exposure and extraordinary sharp spotlight for existence of Islamic schools in Indonesia, especially and the development of educational institutions in Indonesia generally, which still covered a myriad of problems so complexity nowadays.

Seeing the birth history of Islamic schools, from society to society and developed by society, could not be denied its presence had given a real contribution value for the sustainability education of the nation's children. The societies give great contribution in encouraging the birth of various institutional educations in the archipelago, this was evidenced by the existence of boarding school-style education that had existed before the independence of Indonesia. Suharto, as quoted by Azra \& Afrianty (2005) mentions, among the Muslim society of Indonesia, society participation in the framework community-based education has been held longer, as long as the history of Islamic development in Indonesia, ranging from rangkang, dayah, meunasah, (Aceh), surau (Minangkabau), boarding school (Java), bustanul athfal, diniyah and other Islamic schools are established and developed by Muslim society. These institutions are merely examples of how the concept of community- 
based education is applied by Indonesians in the historical trajectory (Azra, 2014, 2015; Pohl, 2006).

Islamic School is isim from the word "darasa" means "learn". So Islamic School means a place of learning for students or college students (Muslims) (Abdullah, 2017; Jackson \& Parker, 2008; Lukens-Bull, 2001; Nor \& Malim, 2014). In the history of Islamic education, the meaning of Islamic School plays an important role as a learning institution for Muslims during its growth and development. Because, using of the term Islamic School definitively just appeared on the bad $11^{\text {th }}$. The explanation of the term Islamic School is a transformation from mosque to Islamic School, there are several theories that developed around transformation process, among others, Makdis (2005) explained that Islamic School is the transformation of Islamic education institution from mosque to Islamic School happens indirectly through three stages: First, mosque stage. Second, mosque-khan; and Third, Islamic School stage.

Furthermore Nizar (2013) suggests that, judging from the historical aspect, the existence Islamic School in the classical XXI century (at present) is not much different. The dynamics of Islamic School grows and takes root from culture of local society will not escape the dynamics and civilization of society (change of society) (Brooks \& Mutohar, 2018; Ghufron \& Nasir, 2019). It is not wrong to say that many Islamic Schools grow and develop from bottom to up. This fact, we often find dead Islamic School, but still exist and in line with the life of local people, even though life is very stagnant. According to historians' different opinions about Islamic School stands, although there are some opinions which are quite representative. Djuwairiyah \& Muqit (2017) reveals that before $10^{\text {th }}$ century it was said that the first Islamic School was al-Baihaqiyah in Nisabur city. It was referred to as al-Baihaqiyah because it was founded by Abu Hasan al-Baihaqi (w.414). This opinion was reinforced by the research of Richard Bullir (1972) which states that two centuries before the establishment of Nizamiyah Islamic School has stood Islamic School in Nisabur, Miyan Dahiya Islamic School who taught Fiqih Maliki. Abd. Al-'Al (1977) explains that at the time of Sulthan Mahmud al-Gasnawi (998-1030) Islamic School Sa'diyah was established. Likewise, Naji Ma'ruf (1973) argues that the first Islamic School was established 165 years before Khurasan. He presented the evidence in Tarekh al-Bukhari explained that Isma'il ibn Ahmad Asad (w.295) visited by their students. In Nizar (2009) argued that Islamic School of the first College was built by Al-Juwaini (475/1063) and Abu Qasim al-Qusyairi (d.465/1072) is in Nisabur (Arifin, 2002; Saleh \& Ikhsan, 2015).

Islamic Education as one of the Islamic educational institutions is the foundation and prototype of continuation of Islamic education system (madrasah) nowadays. Nizam al-Muluk Islamic School, for example is the most popular Islamic School among historians and Islamic societies. It was founded by Nizam al-Muluk a Prime Minister of Salajikah dynasty during the reign of Sulthan Al-Arsham and Sulthan Maliksyah in $5^{\text {th }} \mathrm{H} / 11 \mathrm{M}$ which inaugurated $459 \mathrm{H} / 1067 \mathrm{M}$ (Alfurqan et al., 2020; Isbir, 2017; Ta'rifin, 2010).

Shaleh's opinion (2005: 11-12) suggests that, Islamic School as educational institutions in the form of formal education has been known since the early $11^{\text {th }}$ century or $12 \mathrm{M}$, or $5^{\text {th }}-6^{\text {th }}$ 
century, known Nadzamiyah Islamic School was founded in Baghdad by Nizam Al-Mulk a Wazir of the Seljuq Dynasty. Establishment of Islamic School has enriched the repertoire of educational institutions within the Islamic society, because in earlier times the Islamic society only recognized traditional education which was hold in mosques and dar alhikmah. In Middle East institutions of Islamic School evolved to provide advanced Islamic education (advanced / high), that is to serve those who still hungry for science after a long period of study by studying in mosques and / or dar al-khuttab.

According to Shaleh (2005), the term Islamic School in Indonesia is a modern phenomenon that emerged in the early $20^{\text {th }}$ century. Unlike in Middle East where Islamic School are educational institutions that provide advanced religious science lessons, the term Islamic School in Indonesia refers to educational institutions that provide low-and middle-level Islamic learning. Its development is thought to be more a reaction to the factors that developed from outside of educational institutions that have traditionally existed, especially for rising of western modern education. In other words, the growth of Islamic School in Indonesia is a result of attractiveness between boarding school as an indigenous cultural institution already exists on the one hand, with Western (modern) education on the other. The presence of Islamic School in Indonesia could not be separated from the history of the entry of Islam. Islam came to Indonesia was brought by merchants from Gujarat, in peacefully, without coercion, violence and war. The process of spreading Islam was done by religious leaders who have studied Islam both when they studied in Mecca as well as those Guardians who have developed Islam in this archipelago.
The presence of God's guardians who mastered the science of religion became a torch and light for the population to study Islam properly. The spread of Islam peacefully without compulsion became strong touch and conviction by the people to know the true teachings of Islam. And usually, society or people learn Islam through reading, writing and performing prayer procedures in homes, being violated, in mosques and developing later into boarding school (pesantren).

Islamic School is one of the educational institutions whose status is located in the Ministry of Religious Affairs of the Republic of Indonesia. Long before the independence of Indonesian nation, these Islamic Schools have existed even become the beginning of the birth of other Islamic educational institutions in Indonesia. According to Shaleh (2015), one of the patterns of educational development prior to the independence of Indonesia was pattern of isolative-traditional, in the sense of not accepting anything that smells west (colonial) and obstructed influence of thoughts in Islam to enter into it, as showing it is clear to traditional boarding schools' education which only emphasize Islamic religious sciences and general knowledge are not given

The existence of Islamic School scatters throughout the archipelago, is the result of the initiation of citizens who try to get their children to get a decent education and able to provide maximum service to the fulfillment of their education, so in the end the children become useful human beings, useful for himself, his family and nation (Nizar, 2009). However, not all Islamic Schools exist throughout the archipelago, have been able to provide services and needs that are expected of children, parents and other stakeholders. 
The Ministry of Religious Affairs statistic of Republic Indonesia 2015 , noted there were 72,726 Islamic School institutions. From the total of 72,726 Islamic School, only 9 percent were government-run, while 91 percent were managed by the society through foundations or through self-help societies. From 91 percent of Islamic Schools were managed by the societies, it continued to grow dynamically in line with needs of society. Various policies were owned by the issuance of PMA number 10 of 2010 Directorate of Islamic School Education as a legal shade of Islamic School managers must be based on dynamic analysis in the midst of society. From a sociologically historical factual point of view, Islamic School is a community-based institution. This is in line with the policy and mandate of the Minister of Religious Affairs (PMA) number 10 of 2010 on the Directorate of Islamic School Education (Ditpenma) to perform the task should not be out of the factual historical and sociopsychological aspects of Islamic School. That is, the Directorate of Islamic School Education should see and inlne with the dynamics which develop. Diversification of Islamic School became the key word to develop Islamic School simultaneously (Minister of Ministry RI, Media Indonesia, Friday, December $5^{\text {th }}$ 2014).

According to Hasan (2012) argued that, the existence of Islamic School is a manifestation of the Muslim theologians' consciousness in order to prepare a better future generation. The spirit of society to set up an Islamic School will usually depend on the level of theological awareness of its supporting society. The spirit as khalifah fil Ardh and the needs to harvest and practice his religious jargon (tafaquh fiddin). On the basis of theological awareness, the Muslims feel to have a mandatory burden to realize a good Islamic education and maintain its sustainability. Furthermore, Susilawati (2008) said going backward Islamic School will depend on how much awareness of Muslims to support the Islamic School can choose its sustainability. The institution in addition to being a force of spread of Islam also serves as a society college institution in the long span of time had efforts to educate the nation life.

In the current reform era, the potential of region to be a foundation in development, then the position of Islamic School in its history belongs to society must be restored as before. The Ministry of Religious Affairs must function to provide service, supervision, control and quality control, especially in the development of national standards of Islamic School education and Islamic characteristics in an all-global life and a world without limits. The Ministry of Religion apparatus in education sector should function as controller and supervision service. Thus, Islamic School does not have to appear in uniform and single forms for the whole of Indonesia. The Islamic School should give opportunity to develop in line with the aspirations of society environment. The quality of Islamic School education outcomes will be assessed by the society. Thus, also the death of Islamic School is determined by the society itself (Akhwan, 2008; Nizah, 2016; Shaleh, 2004)

The position of Islamic School in the national education system is recognized as egalitarian as one of the educational institutions who join and contribute in educating the children of nation, this is stated in the announcement of BPKNIP December $22^{\text {th }}, 1945$ (RRI News II and No. 4 and 5-page 20 column 1) suggests that: "in advancing education and teaching at least 
for teaching and education at langgarlanggar and Islamic Schools to continue and to be accelerated". Furthermore, on December $27^{\text {th }}, \quad 1945, \quad$ BPKNIP suggested that Islamic School and boarding schools receive the attention and material assistance from the government, because Islamic School and boarding school are essentially a tool and source of education and intelligence of ordinary people who are rooted in Indonesian society in general. After the establishment of the Ministry of Religion on January $3^{\text {rd }}, 1946$, in addition to the duty of taking care of religious matters, it was also its main duty to eradicate the religious education problems in public schools, and the education problem in religious schools (Islamic School and boarding school). The first task is to provide assistance to Islamic School by issuing Regulation of the Minister of Religious Affairs No. 1 of 1946 and the implementation of religious education in public schools by issuing a Joint Regulation of the Minister of PP \& K and Minister of Religious Affairs No. 1142 / Bhg A (Teaching) on 2-121946 and number 1285 / KJ (Religion) 12-12-1946 which became effective on January $1^{\text {st }}, 1947$.

Based on Presidential Decree No. 136/1999 on the organizational structure of the Ministry of Religious Affairs and Presidential Decree No. $49 / 2002$ on the position, function, organization structure and working procedures of the vertical organization of Religious Affairs Department. The scope of Islamic School development includes: (1) realizing the characteristics and identity of Islamic School as educational units who develop religious life that worship services through activity programs between schools, societies, and families, (2) seeking management independence and education funding are supported by society self-help.
The Islamic School coaching strategy by the Ministry of Religious Affairs, among others through the Islamic School enlightenment program, has a promising future, promising Islamic School and entering employment and continuing school, including: (1) development of model Islamic School (as an agent of change) who invites surrounding Islamic School as a quality Islamic School together. Equipped with facilities, such as libraries, science laboratories, language laboratories, computers, textbooks and educational materials, (2) integrating Islamic School, the integration of Ibtidaiyah, Tsanawiyah and Aliyah Islamic Schools are located in one location. Integration in the framework of administrative integration, curriculum development, institutional utilization, using of facilities, as well as educational financing, and (3) empowerment of Islamic School is intended as an effort to keep the Islamic School survive and become part of the national education system.

Efforts to empower Islamic School in the framework of schoolbased management, as well as efforts to develop community participation in the framework of responsibility by parents and community (community-based management), in addition to Islamic School is also expected to respond toward changes that occur, thus dynamic realizing conditions capable to support efforts to improve the quality of education in Islamic School. Due to the participation of society in education of the main owner of Islamic School, in the National Education System Act number 20 of 2003 Chapter XV Article 54 point 1 and 2 is expressly stated that: (1) the participation of society in education includes the role of assault, family, professional entrepreneurs, and society 
organizations in supervising and managing the quality of education services, (2) societies can participate as sources, implementers, and users of educational outcomes.

\section{CONCLUSION AND RECOMMENDATION}

Comprehensive empowerment of Islamic School will eventually result in educational institutions and institutional figures that have strong and proud character, not only for the leadership of the concerned Islamic School head, but also to bring the atmosphere of enlightenment in the middle of exposure and extraordinary sharp spotlight for the existence of Islamic School in Indonesia, especially and the development of educational institutions in Indonesia generally, which today is still covered by a myriad of problems so complexity.

The existence of Islamic School in Fisherman Society of Suku Bajau Kuala Tungkal has not made a place in the hearts of people. Although managers have done their best to approach the children, they are interested in studying at Islamic School. It is realized that the management of Islamic School is still weak, the awareness of society that has not made Islamic School as a place to study, the environment around Islamic School and minimal facilities, the alignment and policy makers suggested to make the empowerment of Islamic School has not run as expected.

\section{REFERENCES}

Abdullah, M. A. (2017). Islamic Studies in Higher Education in Indonesia: Challenges, Impact and Prospects for the World Community.

Al-Jami'ah:
Journal of Islamic Studies, 55(2), 391-426.

Akhwan, M. (2008). Pengembangan madrasah sebagai pendidikan untuk semua. El Tarbawi, 1(1), $41-54$.

Alfurqan, A., Deprizon, D., \& Hidayat, A. T. (2020). Perkembangan Madrasah Nizamiyah (Analisis Terhadap Lembaga Dan Kurikulum Pendidikan Islam. Tabuah, 24(2), 186-193.

Arifin, M. (2002). Perbandingan Pendidikan Islam. Jakarta: Rineka Cipta.

Azra, A. (2014). Reforms in Islamic education: A global perspective seen from the Indonesian case. Reforms in Islamic Education: International Perspective', London Etc: Bloomsbury, 5975 .

Azra, A. (2015). Genealogy of Indonesian islamic education: Roles in the modernization of muslim society. Heritage of Nusantara: International Journal of Religious Literature and Heritage, 4(1), 85-114.

Azra, A., \& Afrianty, D. (2005). Pesantren and Madrasa: Modernization of Indonesian Muslim Society. Workshop on Madrasa, Modernity and Islamic Education, Boston University, CURA.

Brooks, M. C., \& Mutohar, A. (2018). Islamic school leadership: A conceptual framework. Journal of Educational Administration and History, 50(2), 54-68.

Burga, M. A. (2019). Hakikat Manusia Sebagai Makhluk Pedagogik. Al-Musannif, 1(1), 19-31. 
Daun, H., \& Arjmand, R. (2005). Islamic education. In International Handbook on Globalisation, Education and Policy Research (pp. 377-388). Springer.

Davis, B., \& Sumara, D. (2008). Complexity as a theory of education. TCI (Transnational Curriculum Inquiry), 5(2), 3344.

Denzin, N. K. (2009). Qualitative inquiry under fire: Toward a new paradigm dialogue. Left Coast Press.

Dimitriadis, G., \& Kamberelis, G. (2006). Theory for education. Taylor \& Francis.

Djuwairiyah, D., \& Muqit, A. (2017). Perbandingan Pendidikan Islam. Lisan Al-Hal: Jurnal Pengembangan Pemikiran Dan Kebudayaan, 11(2), 291-306.

Douglass, S. L., \& Shaikh, M. A. (2004). Defining Islamic Education: Differentiation and Applications. Current Issues in Comparative Education, 7(1), 5-18.

Ghufron, M. N., \& Nasir, A. (2019). Pesantren and Disability: The Dynamics of Islamic Boarding School in Accommodating Children with Disabilities. ADDIN, 13(2), 313-336.

Halik, A. (2016). Paradigm of Islamic Education in the Future: The Integration of Islamic Boarding School and Favorite School. Information Management and Business Review, 8(4), 24-32.

Hasan, N. (2009). Islamizing formal education: Integrated Islamic school and a new trend in formal education institution in Indonesia.

Hasan, N. (2012). Education, young Islamists and integrated Islamic schools in Indonesia. Studia Islamika, 19(1).

Hilgendorf, E. (2003). Islamic education: History and tendency. Peabody Journal of Education, 78(2), 63-75.

Hussain, A. (2004). Islamic education: Why is there a need for it? Journal of Beliefs \& Values, 25(3), 317-323.

Isbir, M. (2017). Studi tentang Madrasah Nizhamiyah. Tasyri': Jurnal Tarbiyah-Syari'ah Islamiyah, 24(01), 49-59.

Jackson, E., \& Parker, L. (2008). "Enriched with Knowledge": Modernisation, Islamisation and the Future of Islamic Education in Indonesia. RIMA: Review of Indonesian and Malaysian Affairs, 42(1), 21.

Kellner, D. (2003). Toward a critical theory of education. Democracy \& Nature, 9(1), 51-64.

Ladson-Billings, G., \& Tate, W. F. (2006). Toward a critical race theory of education. Critical Race Theory in Education: All God's Children Got a Song, 11, 30.

Leo, U., \& Wickenberg, P. (2013). Professional norms in school leadership: Change efforts in implementation of education for sustainable development. Journal of Educational Change, 14(4), 403-422.

Lincoln, Y. S. (2007). Naturalistic inquiry. The Blackwell Encyclopedia of Sociology. 
Lukens-Bull, R. A. (2001). Two sides of the same coin: Modernity and tradition in Islamic education in Indonesia. Anthropology \& Education Quarterly, 32(3), 350-372.

Makdisi, G. A. (2005). Cita humanisme Islam: Panorama kebangkitan intelektual dan budaya Islam dan pengaruhnya terhadap Renaisans Barat. Penerbit Serambi.

Merry, M. S. (2018). Indoctrination, Islamic schools, and the broader scope of harm. Theory and Research in Education, 16(2), 162-178.

Mundiri, A. (2017). Organizational Culture Base on Total Quality Management In Islamic Educational Institution. ADRI International Journal of Islamic Studies and Social Sciences, 1(1).

Muthmainnah, F., Raharjo, T. J., \& Khafid, M. (2020). Management of Moral and Systemic Institutions Based on Islamic School Culture. Educational Management, 133138.

Nizah, N. (2016). Dinamika Madrasah Diniyah: Suatu Tinjauan Historis. Edukasia: Jurnal Penelitian Pendidikan Islam, 11(1).

Nizar, H. S. (2013). Sejarah Sosial dan Dinamika Intelektual

Pendidikan Islam di Nusantara. Kencana.

Nor, M. R. M., \& Malim, M. (2014). Revisiting Islamic education: The case of Indonesia. Journal for Multicultural Education.
Pohl, F. (2006). Islamic education and civil society: Reflections on the pesantren tradition in contemporary Indonesia. Comparative Education Review, 50(3), 389-409.

Saleh, M., \& Ikhsan, N. (2015). Perbandingan Sistem Pendidikan di Tiga Negara: Mesir, Iran, dan Turki. Jurnal Pendidikan Islam, 4(1), 49-69.

Salleh, M. S. (2013). Strategizing islamic education. International Journal of Education and Research, 1(6), 1-14.

Shaleh, A. R. (2004). Madrasah dan pendidikan anak bangsa: Visi, misi dan aksi. RajaGrafindo Persada.

Spradley, J. P. (2016). Participant observation. Waveland Press.

Susilawati, S. (2008). Eksistensi madrasah dalam pendidikan Indonesia. Madrasah: Jurnal Pendidikan Dan Pembelajaran Dasar, 1(1).

Tan, C. (2015). Educative Tradition and Islamic School in Indonesia. Jurnal Ilmiah Peuradeun, 3(3), 417-430.

Ta'rifin, A. (2010). Madrasah Nizamiyah: Simbol Patronase Penguasa Sunni Dalam Lembaga Pendidikan. Edukasia Islamika, 8(1), 135125. 